\title{
The Effect of Export Promotion Programs on Export Performance with the Mediating Role of Marketing Implementation Capability: An Empirical Study on Exporting Companies in Ethiopia
}

\author{
Getie Andualem Imiru ${ }^{1}$ \\ ${ }^{1}$ Associate Professor in Marketing Management, School of Commerce, Addis Ababa University, Ethiopia \\ Correspondence: Getie Andualem Imiru, Associate Professor in Marketing Management, School of Commerce, \\ Addis Ababa University, Ethiopia. E-mail: get_aiwo@yahoo.com
}

Received: March 19, 2021 Accepted: April 24, $2021 \quad$ Online Published: May 13, 2021

doi:10.5539/ijms.v13n2p36

URL: https://doi.org/10.5539/ijms.v13n2p36

\begin{abstract}
The area of export performance has been attracting both academic and managerial attention at an increasing pace. The purpose of this study is to examine the effect of Export Promotion Programs on Export Performance mediated by marketing implemenattion capbaility in the case of Exporting Companies in Ethiopia. The target repsondnets of this study were Exporting companies operating in Ethiopia. The total number of exporting companies operating in the country are 938. The number of questionnaires distributed were 280 and 218 (78\%) of the collected questionnaires were used for anlaysis. The validity of the data was tested by measuring construct validity and discriminant validity. Data were analyses using partial least squares Structural Equation Modeling (PLS-SEM). The study findings showed that the use of export promotion programmes has a positive and significant effect on export Performance. Results of the total model also revealed that market implementation capability mediated the effect of Education, Training and Development-related EPPs, Legal-Related EPPs, Marketing Selection-Related EPPs on export performance positively and significantly. On the other hand, Market Implementation Capability didn't mediate the effect of Information-Related EPPs, Financial Aid-Related EPPS, Marketing Strategy-Related EPPs and Miscellaneous EPPs on export performance. Marketing implementation capabilities was found to have a partial mediation role between EPPs and Performance. The findings of the study are expected to provide a source of information for policy makers, researchers and exporters and marketing professionals to understand link between Export Promotion Programs, with the immediate role marketing implementation capability in exporting companies operating in Ethiopia.
\end{abstract}

Keywords: developing country export promotion programme, marketing implementation capability, export performance

\section{Introduction}

The amount of financial, human, and other resource commitments in the export business is relatively lower as compared with other international market entry modes. Exporting provides the firm a high level of flexibility and cost-effectiveness to penetrate into foreign markets quickly (Leonidou, 1995; Leonidou \& Adams Florou, 1999). However, foreign markets are much more diverse than domestic markets and in many instances are more hostile. Thus, exporters are required to develop a high level of understanding about various constructs that affect the level of export performance directly or indirectly. Despite the increased number of studies that have been concerned with export performance, there is no uniformly accepted conceptualization and operationalization of the construct (Cavusgil \& Zou, 1994; Shoham, 1998). Many objective and subjective measures were used in various studies to measure export performance. This large number of different performance measures restricts the advance of the export marketing literature because it makes it hard to compare and contrast the findings obtained from different studies (Zou \& Stan, 1998).

The economic justification for government involvement in export promotion is grounded on the theory of externalities and other market failures associated with export (Lederman et al., 2010). Market failures describe situations in which the free market fails to arrange production and/or consumption in such a way that the allocation of resources is efficient (Borooah, 2003). Many Countries are adopting Government supported EPPS to help actual and Potential exporters to develop a better level of insight about export markets. Francis, 
Collins-Dodd (2004) has described about the Role of Government Supported-EPPs in helping exporting companies to achieve superior performance in overseas markets. Government supported EPPs provides a number of benefits to exporters in the form of giving export information, Export advice, marketing support, financial support and guarantees, and promotional activities abroad (Cavusgil \& Yoeh, 1994). EPPs also helps Company Managers to develop a positive perception toward international operations (Shamsuddoha et al., 2009), reduce mental or actual barriers to exporting (Leonidou, 2004), and enhance the capabilities that are crucial to success in foreign markets (Tesfom \& Lutz, 2008).

Export promotion Programs are practiced by developed as well as developing countries and covers a multitude of policy interventions which may range from public goods provision to exchange rate policies, from financial assistance to marketing and advertising services. The relationship between EPPS and Export performance in the target export market is not straight forward and simple, rather it is complex. In many export marketing literatures and studies, Marketing implementations capability was also identified as a critical link between Government supported EPPS and Export performance in the target export market (Cavusgil \& Zou, 1994). In this study, the role of EPP on export performance was examined in relation to the mediating role of Marketing capability of the export Business.

Government Supported EPPs were found to include information, finance, education and training, legal framework, Market Selection, Marketing Strategy (product, price, distribution, promotion) and Miscellaneous. Government Supported-EPPs may be necessary, but not enough for firms to compete in international markets (Gengtiirk \& Kotabe, 2001; Seringhaus, 1986). Previous studies have shown inconsistent evidence regarding the effect of EPPs on export Performance. Some of the previous studies showed the positive \& significant effect of EPPs on export Performance (Lages \& Montgomery, 2005; Shamsuddoha et al., 2009), while others (for example, Freixanet, 2014) showed the effect of EPPs on export performance is insignificant. Thus, the effect of EPPs on export performance remained inconclusive to date due to the requirement of other intervention variables.

\section{Export Performance}

Export provides one of the most common routes to enter international markets spurred by its greater structural and strategic flexibility compared to alternatives such as foreign direct investment and international aid (Leonidou et al., 2011). Export performance is the relative success or failure of the efforts of a firm or nation to sell domestically produced goods and services to other nations. Despite the increased number of studies that have been done in relation to export performance, there is no uniformly accepted conceptualization and operationalization of the construct (Cavusgil \& Zou, 1994; Shoham, 1998). The export performance measures were classified as objective and subjective measures in export performance literatures. From the export literature, objective measures were based on absolute values such as export intensity, export sales volume, and export market share, among others. On the other hand, subjective measures are related to perceptual or attitudinal performance which includes perceived export success and satisfaction with export sales, perception of the overall export performance in relation to market share, sales revenue, acquiring new overseas customers;, export sales, overall export performance compared to competitors, export success, meeting expectations, rating firm's export performance by competitors, return on investment, quality of distributor relationship, customer satisfaction, and satisfaction with product/service quality compared to competitors. This large number of different performance measures restricts the advance of the export marketing literature because it makes it hard to compare and contrast the findings from different studies (Zou \& Stan, 1998).

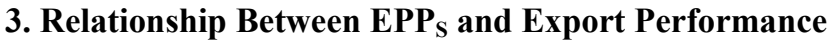

\subsection{Information-Related Export Promotion Program \& Export Performance}

If companies lack adequate information when they enter into an unfamiliar foreign market their performance will naturally be inferior. Toften and Olsen (2003) conceptualized the causal relationship between knowledge and export performance, and proposed that a firm which use an internal and external information develop explicit and tacit knowledge will contribute to the firm's export performance. Possessing adequate, relevant, and accurate information is of paramount importance for the exporting firm, due to the high uncertainty, heterogeneity, and volatility characterizing the international business environment (Welch \& Wiedersheim-Paul, 1980)

\subsection{Financial Aid-Related Export Performance Program and Export Performance}

Cross boarder trading involves excessive costs including researching overseas target markets, adapting products and packaging, transportation costs, additional taxes, and so on. Wiklund and Shepherd (2005) indicated access to financial resource facilitates entrepreneurial orientation and ultimately magnifies its performance. Companies with a low level of adoption of the financial aid-related EPPs are constrained in deploying their resources in 
order to transform export marketing strategy into realized actions. Access to financial resource amplifies the complementary effect of entrepreneurial and market orientations on the success of export of new products, Boso et al.'s (2012)

\subsection{Education and Training-Related Export Performance Program and Export Performance}

Educating potential exporters to gain relevant skills, knowledge, and experience are critical to be successful in the export target market. Government EPPS offers specialized seminars, conferences, and workshops, aiming to help Companies to develop a better level of understanding their export mechanics, handling export documentation, and developing export marketing plans and in improving their negotiation skills. However, Leonidou et al. (2011) contended that the impact of EPPs on organizational resources and capabilities is greater for small Companies than larger companies for the inexperienced exporters than experienced exporters.

\subsection{Legal-Related Export Promotion Programs and Export Performance}

Export companies are encountering difficulties in an overseas market. There are many restrictions in importing countries including price control, special tax rates, exchange controls which create difficulties in repatriating the firm's profits tariffs, subsidies, quotas and full- scale import bans. among others. Special export assistance programs on legal advice including dispute handling techniques associated with foreign distributor agreement, tax authorities, and repatriation of funds are offered. To accommodate these restrictions governments have undertaken internal bureaucratic reforms such as consolidating various scattered export-related formalities under the umbrella of a single government agency (Kumku et al., 1995).

\subsection{Market Selection-Related Export Promotion Programs and Export Performance}

There are more than 200 countries in the world, thus while selecting the potential market the strongest attention should be given to political and economic environment. Many firms initiate exports as a response to unsolicited orders from foreign customers, rather than as a result of their own systematic efforts to explore foreign markets (Samiee et al., 1993). Gaston-Breton and Martin (2011) state that selection of foreign market is an important question in the strategy of international marketing and international business, as well as in management of that business. Gallego, Hidalgo, Acedo, Casillas and Moreno (2009) state that a company while searching for potential foreign markets anticipates that its activity will be profitable. The ultimate purpose of market selection export promotion program is to provide a sound 'matchmaking' service between the exporter and potential import buyers that will guarantee a prosperous, long-term working relationship

\subsection{Marketing Strategy-Related Export Promotion Program \& Export Performance}

According to Jaramillo (1992), Governments offer a range of specialized EPPs such as matching the company's products with foreign buyers' needs, developing new products for specific overseas markets, advising product modification requirements, provision of packaging configuration across countries and improving product quality for export purposes. Government provides guidance in setting the firm's prices in different countries, taking into consideration of cost structures, buyer disposable incomes, and competitors' prices; finding right currency to be used in transactions with foreign buyers, accommodating foreign exchange risks and determining prices to increase the chances of successful contract bidding. According to Wilkinson and Brothers (2000), many governments offer assistance to exporters in locating distributors/agents in foreign markets and provide highlights to their economic (financial) and non-economic (reliability) position. Exporters are given money and other facilities to invite business people, government officials, journalists, and other influential people from abroad to visit their home country to establish business relationships and at times exporters receive financial assistance to personally visit foreign markets, in order to explore business opportunities, identify prospective buyers, and obtain good representation.

\subsection{Miscellaneous Export Promotion Program \& Export Performance}

A series of other government programs aims to encourage exporters to enter into a target export market. National Export Award Scheme (Marandu, 1995), Public recognitions offered by the government and other professional associations to successful exporters in order to enhance their own operations (Kumku et al., 1995), the establishment of trade offices abroad by the government to provide information to current and potential exporters (Tesfom \& Lutz, 2008) are critical to be successful in an overseas market.

\section{Export Promotion Program (EPP $\left.{ }_{S}\right)$ and Marketing Implementation Capabilities}

Government EPPs programs are used to help companies to develop managers' positive perception toward international operations (Shamsuddoha et al., 2009), reduce mental or actual barriers to exporting (Leonidou, 2004), and enhance the capabilities that are crucial to success in foreign markets (Tesfom \& Lutz, 2008). 
According to Morgan (2012), effective marketing strategy implementation involves not only combining and deploying currently held capabilities but also acquiring additional capabilities. Government EPPs are public policy measures offered to exporting business with the aim of improving international competitiveness of domestic firms (Lages \& Montgomery, 2005). The domain of EPPs includes giving export information and advice, marketing support, financial support and guarantees, and promotional activities abroad (Cavusgil \& Yoeh, 1994).

H-1: Information-Related Export Promotion Program has a positive and significant effect on Marketing Implementation Capabilities

H-2: Financial Aid-Related Export Promotion Program has a positive and significant effect on Marketing Implementation Capabilities

H-3: Education and Training-Related Export Promotion Program has a positive and significant effect on Marketing Implementation Capabilities

H-4: Legal-Related Export Promotion Programs has a positive and significant effect on Marketing Implementation Capabilities

H-5: Market Selection-Related Export Promotion Programs has a positive and significant effect on Marketing Implementation Capabilities

H-6: Marketing Strategy-Related Export Promotion Program has a positive and significant effect on Marketing Implementation Capabilities

H-7: Miscellaneous Export Promotion Program has a positive and significant effect on Marketing Implementation Capabilities.

\section{Mediating Role of Marketing Implementation Capability}

Marketing implementation capabilities are concerned with strategy execution as they are "the routines by which export ventures transform intended export marketing strategy into realized actions and resource deployments" (Morgan et al., 2003, p. 295). Many studies support the existence of a positive relationship between marketing capability and organizational performance (Tsai \& Shih, 2004; Vorhies \& Morgan, 2003; Fahy et al., 2000). Without marketing implementation capabilities, resources can't be transformed into value offerings in marketplace. Export Promotion Programs (EPPs) would be ineffective if the company does not have the capability to utilize different types of EPPs and transform it into real actions. Therefore, EPPs may be necessary, but not sufficient for firms to compete in international markets (Gengtiirk \& Kotabe, 2001; Seringhaus, 1986). Dynamic capabilities theory suggests the critical drivers of marketing strategy implementation derive from translating marketing strategy decisions into appropriate capability deployments (Morgan \& Vorhies, 2012).

H8: Marketing Implementation Capabilities mediates all Export Promotion Program (EPPS) on export performance.

H9: Marketing Implementation Capabilities mediates the effect of Information-Related Government EPP on export performance,

H10: Marketing Implementation Capabilities mediates the effect of Financial Aid-Related Government EPPS on export performance,

H11: Marketing Implementation Capabilities Mediates the Effect of Education, Training, and Development Government EPPS on Export Performance.

H12: Marketing implementation capabilities mediates the effect of Legal -Related Government EPPS on export performance.

H13: Marketing implementation capabilities mediates the effect of Marketing Selection -Related Government EPPS on export performance.

H14: Marketing Implementation Capabilities mediates the effect of Marketing Strategy -Related Government EPPS on export performance.

H15: Marketing Implementation Capabilities mediates the effect of Miscellaneous -Related Government EPPS on export performance.

\section{Theoretical Framework of the Study}

Export promotion is a government effort to expand the volume of a country's exports thorough industrial policies or incentives, foreign investment policies and other interventionist policies in order to achieve sustained 
economic growth. In order to give a theoretical underpinning for this study Hechsher-Ohlin factor endowment trade theory and Theory of Developmental State are briefly addressed.

\subsection{Hechsher-Ohlin Factor Endowment Trade Theory}

Eli Heckscher and Bertil Ohlin (1991), the two Swedish economists, focused their attention on how a country could gain comparative advantage by producing products that utilized factors that were in abundance in the country. Provided demand patterns do not differ much between countries, the Hechscher-Ohlin theorem of trade states that: "countries will export those goods whose production is relatively intensive in the factor with which they are well endowed" (Winters, 1991, p. 31). The HO trade theory provides the rational to justify our export promotion strategy because it is logical that industrial countries, which had plenty of capital, should specialize in capital-intensive sectors of the economy while less developed countries (LDCs), with their cheap labour, should invest in labor-intensive industries (Biel, 2000, p. 81).

\subsection{Theory of Developmental State}

Government or States have played a strategic role in taming domestic and international market forces and harnessing them to a national economic interest (White \& Wade, 1988, p. 1). "The modern notion of 'development' rests on a concept of the state as the primum mobile of socio-economic progress. It draws on the historical argument" (Gerashchenko, 1966) that successful 'late development' takes a form very different from that of the early industrialisers, notably United Kingdom: it is less 'spontaneous', more the subject of teleological determination, which the state playing the role of historical animateur. 'Guided market economies' are market economies in which the state tries to achieve its objective by influencing the market—by shifting the composition of what is profitable (White \& Wade, 1988, p. 5).

In this study the effect of different types of EPPs on export performance are mediated by marketing implementation capabilities, as presented in Figure 1. All EPPs are assumed to enhances firm's marketing implementation capabilities, which in turn, drive superior export performance.

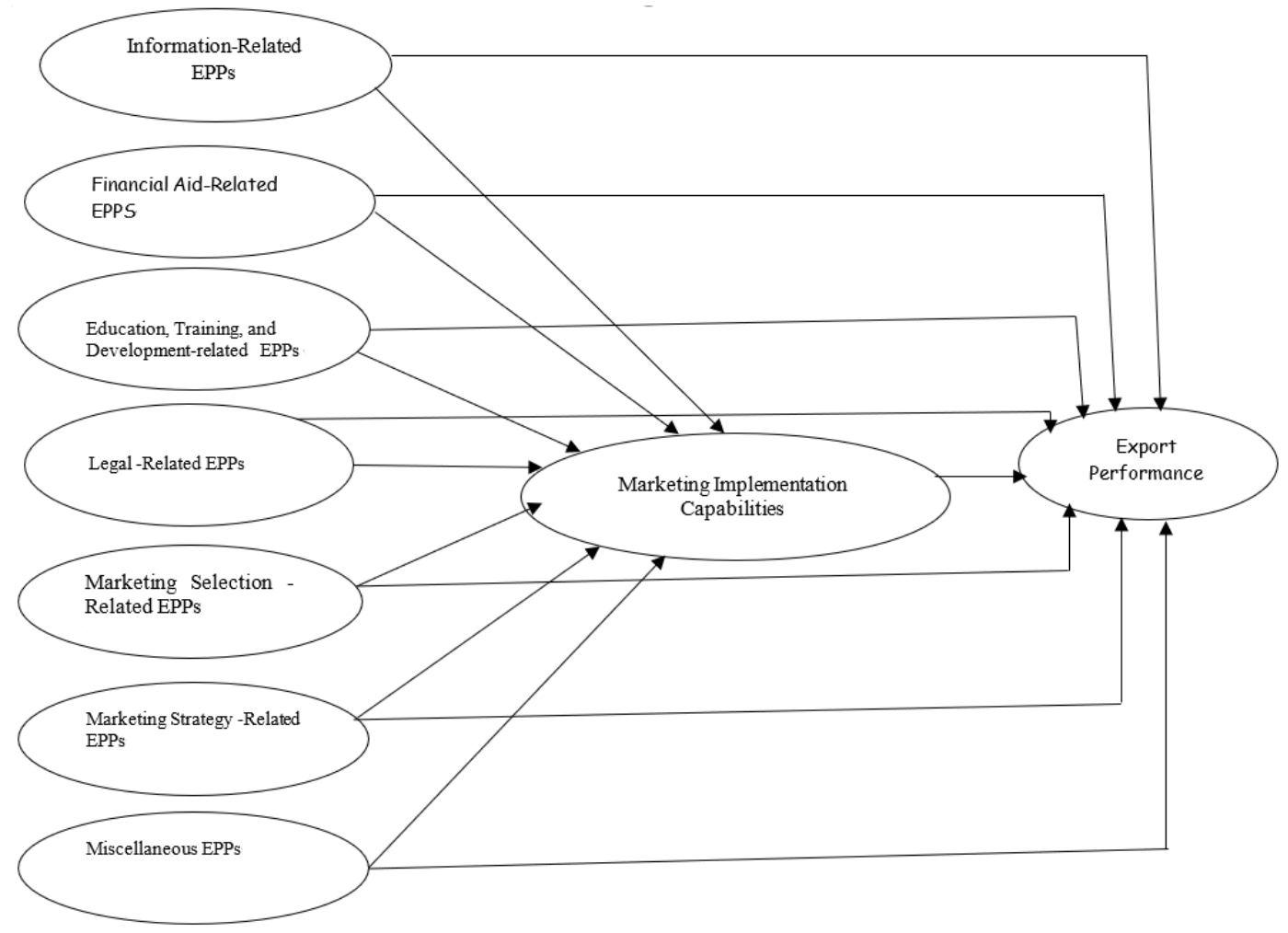

Figure 1. Research model 


\section{Research Methodology}

\subsection{Research Setting \& Research Design}

Ethiopia has a large domestic market of over 100 million people, making it the second most populous country in Africa after Nigeria. Over the last decade, Ethiopia has had one of the fastest growing economies in the world, with an average annual growth rates ranging from 7\% to $12 \%$ (depending on data sources). In 2018, Ethiopia's real Gross Domestic Product (GDP) expanded by 7.7 percent, and is expected to grow by $8.5 \%$ in 2019 , according to the World Bank. However, Ethiopia faces a growing trade deficit with total imports steadily increasing on average by $12.5 \%$ per year during the previous 10 years. Concerned by the widening trade balance, the Government of Ethiopia works to suppress imports and took other macro-economic measures in recent yea such as EPPs. Among others. In this study a cross sectional and a causal research design was used to test the hypotheses with data collected from exporting companies operating in Ethiopia

\subsection{Population and Sampling}

A single country, Ethiopia, was selected as the context of this research to control heterogeneity of export promotion programmes across countries. Firms in three major export orientated industries (garment, leather and leather products and specialized textiles) formed the population of the study. A stratified random sample of 280 firms were selected from the sampling frame of 938 firms provided by several government departments and trade associations of these industries.

\subsection{Research Instrument}

The preliminary version of the questionnaire was initially reviewed by five (5) academics and five (5) marketing practicners to evaluate the contents of the measures selected. The questionnaire contains 4 sections: Section 1 contains demographic variables; Section 2 contains Government Export Promotion Programs (EPPs); Section 3 consists of Marketing Implementation Capabilities; Section 4 contains export performance questions designed based on 5-point Likert scales. Once the questionnaire was designed, its validity and reliability were measured.

\section{Research Findings}

\subsection{Profile of Respondents}

Table 1. Profile of respondents

\begin{tabular}{llll}
\hline Item & Description & Frequency & $\%$ \\
\hline Year of experience in international market & $1-5$ years & 11 & $5 \%$ \\
& $6-10$ & 72 & $33 \%$ \\
& $11-20$ & 100 & $46 \%$ \\
& 21 or more & 35 & $16 \%$ \\
Number of markets the firm operates & Total & 218 & $100 \%$ \\
& $1-3$ & 52 & $24 \%$ \\
& $4-6$ & 68 & $31 \%$ \\
Type of products & $7-10$ & 76 & $35 \%$ \\
& More than 10 & 22 & $10 \%$ \\
& Total & 218 & $100 \%$ \\
& Agricultural products & 172 & 79 \\
& Industrial products & 46 & 21 \\
& Total & 218 & $100 \%$ \\
\hline
\end{tabular}

\subsection{Testing for Non-Response Bias}

In this study 280 questionnaires were distributed and 218 usable questionnaires were collected with a response rate of $78 \%$. The mean difference between the early and the late respondents' responses to the questionnaire was found to be not significant indicating any non-response bias. An independent t-test was used to test the non-response rate. This study used $50 \%$ of the collected data half of which are early respondents and half of them are late respondents. The t-tests results showed that for almost all of the items $(98.24 \%)$ there was no significant difference between the late and early respondents $(p>.05)$ indicating that non-response bias was not a problem for the data.

\subsection{Measurement Models}

\subsubsection{Reliability and Validity}

Before analyzing the data by WarPLS 5 statistical tool, the data were first inserted in to SPSS and a preliminary 
stage of measurement item was first identified by an exploratory factor analysis using by principal components analysis (PCA). The psychometric properties of the measurement model in terms of internal consistency, reliability, convergent validity, and discriminant validity were evaluated. By using SPSS 20, principal component analysis, Measure of sampling adequacy, reliability and validity measure were verified. But lower loading items below the minimum criteria of 0.50 removed from the items (Hair et al., 1998). Factor analysis is used as a data reduction technique which is also used to identify then loaded items that tapped on a same construct.

Subsequently, the constructs and items were used as input in an exploratory factor analysis to test the Measurement model, using WarPLS 5. The structural equation modeling (SEM) WarpPLS 5.0 statistical tool was used for data analysis. The WarPLS 5.0 applies the partial least squares and is a powerful statistical tool because it has ten powerful Goodness-of-fit indices, p-values and multicollinearity estimates. These include: Average path coefficient (APC), average r-squared (ARS) and average variance inflation factor (AVIF), average adjusted R-squared (AARS), average full collinearity VIF (AFVIF), Tenenhaus GoF (GoF), Simpson's paradox ratio (SPR), R-squared contribution ratio (RSCR), statistical suppression ratio (SSR), and nonlinear bivariate causality direction ratio (NLBCDR) (Kock, 2011). The PLS-SEM was favorably selected in this study because it is better suited for complex models with large number of constructs and links (Pavlou \& Fygenson, 2006; Ahuja et al., 2007; Au et al., 2008) and equally important PLS-SEM is more suitable than other statistical tools for testing the effects of moderators (Pavlou \& Sawy, 2006).

\subsubsection{Reliability and Validity Using WarpPLS}

A measurement instrument has good reliability if the question-statements (or other measures) associated with each latent variable are understood in the same way by different respondents. A common statistic for evaluating reliability is the coefficient of internal consistency (Cronbach's Alpha). This statistic should be computed for each of the factors that passed all tests of validity. The recommended and widely accepted threshold in the literature is 0.7 (Hair et al., 2010). According to Chin et al. (1996, p. 33), while Cronbach's alpha with its assumption of parallel measures represents a lower bound estimate of internal consistency, a better estimate can be gained using the composite reliability. The results suggest the Cronbach's alpha of all the research variables has an acceptable reliability and it is more than 0.70. The Cronbach's alpha of the variable of Information-Related to Government EPP is 0.83, Financial Aid-Related Government EPPS is 0.79, Education, Training, and Development Government EPPs is 0.74, Legal Related Government EPPs is 0.83, Marketing Selection-Related EPPs is 0.72, Marketing Strategy-Related EPPs is 0.79, Miscellaneous-Related EPPs is 0.86, Marketing Implementation Capabilities is 0.76 and Export performance is 0.85 . Since the questions of the questionnaire were extracted in consultation with experts from authentic articles, they have proper reliability or validity.

Table 2. Measure of reliability by SEM WarPLS

\begin{tabular}{ll}
\hline Variables & Measure of Cronbach Alpha \\
\hline Information-Related to Government EPP & 0.813 \\
Financial Aid-Related Government EPPS & 0.793 \\
Education, Training, and Development Government EPPs & 0.739 \\
Legal Related Government EPPs & 0.835 \\
Marketing Selection -Related EPPs & 0.717 \\
Marketing Strategy -Related EPPs & 0.785 \\
Miscellaneous-Related EPPs & 0.860 \\
Marketing Implementation Capabilities & 0.777 \\
Export performance & 0.808 \\
Overall, all & 0.849 \\
\hline
\end{tabular}

To test the hypotheses, Structural Equation Model used by WarPLS models. 
Table 3. Latent variable coefficient measurement

\begin{tabular}{lccccccccc}
\hline & Inform & Finaid & Edtrain & Legal & marsel & Marstr & Miscell & MaImpca & Experf \\
\hline R-squared coefficients & & & & & & 0.516 & & & 0.664 \\
Adjusted R-squared & & & & & & 0.479 & & & 0.635 \\
Q-squared coefficients & & & & & & 0.566 & & 0.720 \\
Composite reliability & 0.878 & 0.789 & 0.831 & 0.858 & 0.716 & 0.864 & 0.814 & 0.900 & 0.789 \\
Cronbach's alpha & 0.813 & 0.793 & 0.739 & 0.835 & 0.717 & 0.785 & 0.860 & 0.777 & 0.808 \\
Average variances extracted & 0.644 & 0.560 & 0.622 & 0.549 & 0.462 & 0.480 & 0.605 & 0.818 & 0.555 \\
Full collinearity VIFs & 1.743 & 1.700 & 2.077 & 2.022 & 1.422 & 1.904 & 2.057 & 1.489 & 2.141 \\
\hline
\end{tabular}

Several estimates are provided for each latent variable; these can be used in research reports for discussions on the measurement instrument's reliability, discriminant and predictive validity, as well as overall collinearity. R-squared, adjusted R-squared, and Q-squared coefficients are provided only for endogenous latent variables; and reflect the percentages of explained variance and predictive validity associated with each of those latent variables, respectively. Composite reliability and Cronbach's alpha coefficients are provided for all latent variables.

Composite reliability is a measure of reliability and composite reliability is a better estimate than using Cronbach's alpha. According to Chin et al. (2002), while Cronbach's alpha with its assumption of parallel measures represents a lower bound estimate of internal consistency, a better estimate can be gained using the composite reliability. Q-squared coefficient is a nonparametric measure traditionally calculated via blindfolding. It is used for the assessment of the predictive validity (or relevance) associated with each latent variable block in the model, through the endogenous latent variable that is the criterion variable in the block (Kock, 2014; Kock \& Gaskins, 2014). The Q-squared coefficient is sometimes referred to as a resampling analog of the R-squared coefficient. It is often similar in value to that measure; even though the Q-squared coefficient can more easily assume negative values. Acceptable predictive validity in connection with an endogenous latent variable is suggested by a Q-squared coefficient greater than zero.

\subsubsection{Construct Validity}

Construct validity assesses the extent to which a set of measured items reflect the underlying factor model that those items are designed to measure (Hair et al., 2010). The construct validity focuses on the measurement of individual constructs. Two construct validity assessments convergent and discriminant were tested. The tests were undertaken for the full measurement model (Lewis et al., 2005). This section provides an overview of convergent and discriminant validity and reports the results of the construct validity of the measurement model.

\subsubsection{Discriminant Validity}

Discriminant validity measures to what extent latent variables differ from each other. In contrast to convergent validity, which is a measure within latent variables, discriminant validity is a measure between variables. Discriminant validity can be assessed based on correlations between different constructs. High correlations (above 0.8 or 0.9 ) between constructs indicate a lack of discriminant validity (Holmes-Smith, 2007). Discriminant validity is shown when each measurement item correlates weakly with all other constructs except for the one to which it is theoretically associated. Discriminant validity is shown when two things happen: 
Table 4. Factor structure matrix of loadings and cross-loadings

\begin{tabular}{|c|c|c|c|c|c|c|c|c|c|c|c|c|}
\hline & Inform & Finaid & Edtrain & Legal & marsel & Marstr & Miscell & MaImpca & Experf & Type of construct & $\mathrm{SE}$ & P-value \\
\hline IREP1 & 0.815 & -0.35 & 0.023 & 0.346 & -0.008 & -0.419 & -0.033 & 0.103 & -0.073 & Reflect & 0.08 & $<0.001$ \\
\hline IREP2 & 0.879 & -0.069 & -0.278 & -0.048 & 0.231 & -0.123 & 0.002 & 0.106 & -0.056 & Reflect & 0.079 & $<0.001$ \\
\hline IREP3 & 0.794 & 0.148 & 0.175 & 0.106 & 0.088 & 0.073 & 0.214 & -0.141 & -0.155 & Reflect & 0.081 & $<0.001$ \\
\hline IREP4 & 0.712 & 0.321 & 0.121 & -0.456 & -0.373 & 0.55 & -0.203 & -0.091 & 0.325 & Reflect & 0.082 & $<0.001$ \\
\hline FREP1 & 0.067 & 0.76 & 0.142 & 0.444 & -0.038 & -0.15 & 0.102 & -0.088 & -0.154 & Reflect & 0.081 & $<0.001$ \\
\hline FREP2 & 0.107 & 0.86 & -0.137 & -0.239 & 0.006 & 0.039 & -0.258 & -0.092 & 0.211 & Reflect & 0.079 & $<0.001$ \\
\hline FREP4 & -0.236 & 0.602 & 0.016 & -0.219 & 0.039 & 0.133 & 0.239 & 0.244 & -0.106 & Reflect & 0.085 & $<0.001$ \\
\hline ETDEP2 & -0.057 & -0.028 & 0.868 & -0.216 & -0.004 & 0.088 & -0.196 & 0.118 & 0.308 & Reflect & 0.079 & $<0.001$ \\
\hline ETDEP3 & -0.226 & 0.138 & 0.714 & 0.216 & 0.069 & -0.219 & 0.349 & 0.32 & -0.615 & Reflect & 0.082 & $<0.001$ \\
\hline ETDEP4 & 0.272 & -0.096 & 0.776 & 0.044 & -0.059 & 0.102 & -0.102 & -0.427 & 0.221 & Reflect & 0.081 & $<0.001$ \\
\hline LREP2 & -0.05 & 0.051 & 0.354 & 0.751 & 0.016 & -0.033 & 0.413 & -0.257 & -0.521 & Reflect & 0.082 & $<0.001$ \\
\hline LREP3 & -0.105 & 0.224 & 0.245 & 0.774 & -0.07 & 0.032 & 0.149 & -0.395 & 0.195 & Reflect & 0.081 & $<0.001$ \\
\hline LREP4 & -0.005 & -0.116 & -0.469 & 0.834 & -0.113 & 0.013 & 0.027 & 0.184 & 0.111 & Reflect & 0.08 & $<0.001$ \\
\hline LREP5 & 0.21 & 0.02 & -0.605 & 0.695 & -0.21 & 0.175 & -0.408 & 0.37 & 0.472 & Reflect & 0.083 & $<0.001$ \\
\hline LREP6 & -0.037 & -0.204 & 0.56 & 0.636 & 0.445 & -0.209 & -0.258 & 0.14 & -0.285 & Reflect & 0.084 & $<0.001$ \\
\hline MREP2 & 0.25 & -0.537 & 0.044 & 0.359 & 0.566 & -0.693 & 0.213 & -0.085 & -0.362 & Reflect & 0.086 & $<0.001$ \\
\hline MREP4 & -0.222 & 0.387 & -0.122 & 0.039 & 0.664 & -0.026 & 0.07 & 0.269 & 0.044 & Reflect & 0.083 & $<0.001$ \\
\hline MREP5 & 0.008 & 0.06 & 0.071 & -0.506 & 0.790 & 0.519 & -0.211 & -0.165 & 0.223 & Reflect & 0.081 & $<0.001$ \\
\hline MSTEP2 & -0.207 & -0.201 & -0.257 & 0.032 & 0.107 & 0.589 & 0.23 & 0.449 & 0.009 & Reflect & 0.085 & $<0.001$ \\
\hline MSTEP3 & -0.025 & -0.271 & 0.095 & 0.715 & -0.029 & 0.804 & -0.081 & 0.391 & -0.495 & Reflect & 0.08 & $<0.001$ \\
\hline MSTEP4 & -0.032 & 0.01 & 0.099 & 0.22 & 0.147 & 0.773 & -0.155 & -0.005 & -0.022 & Reflect & 0.081 & $<0.001$ \\
\hline MSTEP6 & 0.155 & 0.475 & -0.012 & -0.971 & -0.128 & 0.638 & -0.067 & -0.528 & 0.445 & Reflect & 0.084 & $<0.001$ \\
\hline MSTEP7 & 0.123 & 0.28 & -0.07 & -0.592 & -0.021 & 0.666 & 0.063 & -0.176 & 0.347 & Reflect & 0.083 & $<0.001$ \\
\hline MSTEP9 & 0.021 & -0.175 & -0.055 & -0.008 & 0.102 & 0.764 & -0.06 & 0.071 & 0.219 & Reflect & 0.081 & $<0.001$ \\
\hline MSTEP12 & -0.053 & -0.046 & 0.165 & 0.442 & -0.235 & 0.58 & 0.166 & -0.304 & -0.47 & Reflect & 0.085 & $<0.001$ \\
\hline MSEP1 & 0.002 & -0.162 & 0.166 & 0.27 & -0.104 & 0.096 & 0.884 & 0.132 & -0.337 & Reflect & 0.079 & $<0.001$ \\
\hline MSEP2 & 0.071 & 0.017 & -0.011 & 0.034 & -0.016 & -0.111 & 0.877 & -0.097 & 0.293 & Reflect & 0.079 & $<0.001$ \\
\hline MSEP3 & -0.124 & 0.25 & -0.267 & -0.524 & 0.207 & 0.023 & 0.513 & -0.063 & 0.079 & Reflect & 0.087 & $<0.001$ \\
\hline MICA1 & -0.174 & 0.121 & 0.114 & -0.099 & -0.021 & -0.036 & 0.279 & 0.904 & -0.014 & Reflect & 0.078 & $<0.001$ \\
\hline MICA2 & 0.174 & -0.121 & -0.114 & 0.099 & 0.021 & 0.036 & -0.279 & 0.904 & 0.014 & Reflect & 0.078 & $<0.001$ \\
\hline EXP1 & 0.027 & -0.137 & -0.159 & -0.251 & 0.245 & -0.206 & 0.128 & 0.146 & 0.774 & Reflect & 0.081 & $<0.001$ \\
\hline EXP3 & 0.124 & -0.086 & 0.181 & -0.349 & -0.172 & 0.135 & -0.112 & -0.028 & 0.777 & Reflect & 0.081 & $<0.001$ \\
\hline EXP4 & -0.172 & 0.254 & -0.026 & 0.683 & -0.082 & 0.079 & -0.018 & -0.133 & 0.681 & Reflect & 0.083 & $<0.001$ \\
\hline
\end{tabular}

- When the correlation of the latent variable score with measurement item need to show an appropriate pattern of loading, one in which the measurement item load highly on their theoretically assigned factor and not highly on other factors.

- When the square root of AVE in each latent variable can be used to establish discriminant validity, if this value is larger than other correlation values among the latent variables (Fornell \& Larcker, 1981). The square root of AVE is put on the diagonal of the table as it depicted in Table 4. For example, in this study, the latent variable 'Inform' AVE is found to be 0.643 hence its square root becomes 0.802 . This number is larger than the correlation values in the column of Inform'. The result indicates that discriminant validity is well established.

Table 5. Correlation and discriminant validity

\begin{tabular}{llllllllll}
\hline & Inform & Finaid & Edtrain & Legal & marsel & Marstr & Miscell & MaImpca & Experf \\
\hline Inform & 0.802 & & & & & & & & \\
Finaid & 0.209 & 0.748 & & & & & & & \\
Edtrain & 0.294 & 0.222 & 0.789 & & & & & & \\
Legal & 0.111 & 0.270 & 0.499 & 0.741 & & & & & \\
marsel & 0.095 & 0.392 & 0.156 & 0.153 & 0.680 & & & & \\
Marstr & 0.165 & 0.010 & 0.407 & 0.371 & 0.261 & 0.693 & & & \\
Miscell & 0.566 & -0.035 & 0.355 & 0.293 & 0.152 & 0.269 & 0.778 & & \\
MaImpca & 0.312 & 0.148 & 0.144 & -0.194 & 0.086 & 0.289 & 0.174 & 0.904 & \\
Experf & 0.273 & 0.151 & 0.629 & 0.697 & 0.203 & 0.192 & 0.503 & -0.068 & 0.745 \\
\hline
\end{tabular}




\subsubsection{Convergent Validity}

The ideal level of standardized loadings for reflective indicators is 0.7 but 0.6 considered to be an acceptable level (Barclay et al., 1995). For all the constructs with multiple measures, all items have high loadings, with majority above 0.7 therefore demonstrating convergent validity.

Table 6. Factor loading

\begin{tabular}{|c|c|c|c|c|}
\hline Construct & Indicator & Loading & P value & VIF \\
\hline \multirow[t]{4}{*}{ Information-Related EPPs } & IREP1 & 0.617 & $<0.014$ & 1.979 \\
\hline & IREP2 & 0.741 & $<0.013$ & 2.462 \\
\hline & IREP3 & 0.609 & $<0.012$ & 1.712 \\
\hline & IREP4 & 0.677 & $<0.011$ & 1.393 \\
\hline \multirow[t]{3}{*}{ Financial Aid-Related EPPS } & FREP1 & 0.752 & $<0.010$ & 1.327 \\
\hline & FREP2 & 0.812 & $<0.009$ & 1.472 \\
\hline & FREP4 & 0.659 & $<0.008$ & 1.135 \\
\hline \multirow[t]{3}{*}{ Education, Training, and Development Epps } & ETDEP2 & 0.665 & $<0.007$ & 1.668 \\
\hline & ETDEP3 & 0.683 & $<0.006$ & 1.274 \\
\hline & ETDEP4 & 0.716 & $<0.005$ & 1.424 \\
\hline \multirow[t]{5}{*}{ Legal Related Government EPPs } & LREP2 & 0.673 & $<0.004$ & 2.157 \\
\hline & LREP3 & 0.682 & $<0.003$ & 1.878 \\
\hline & LREP4 & 0.704 & $<0.002$ & 2.931 \\
\hline & LREP5 & 0.653 & $<0.001$ & 2.32 \\
\hline & LREP6 & 0.731 & $<0.000$ & 1.472 \\
\hline \multirow[t]{3}{*}{ Marketing Selection -Related EPPs } & MREP2 & 0.821 & $<0.001$ & 1.049 \\
\hline & MREP4 & 0.879 & $<0.001$ & 1.081 \\
\hline & MREP5 & 0.770 & $<0.010$ & 1.129 \\
\hline \multirow[t]{7}{*}{ Marketing Strategy -Related EPPs } & MSTEP2 & 0.675 & $<0.009$ & 1.427 \\
\hline & MSTEP3 & 0.639 & $<0.008$ & 2.723 \\
\hline & MSTEP4 & 0.630 & $<0.007$ & 2.37 \\
\hline & MSTEP6 & 0.690 & $<0.006$ & 1.76 \\
\hline & MSTEP7 & 0.698 & $<0.005$ & 1.797 \\
\hline & MSTEP9 & 0.627 & $<0.004$ & 1.724 \\
\hline & MSTEP12 & 0.672 & $<0.003$ & 1.344 \\
\hline \multirow[t]{3}{*}{ Miscellaneous-Related EPPs } & MSEP1 & 0.887 & $<0.002$ & 1.875 \\
\hline & MSEP2 & 0.883 & $<0.001$ & 1.855 \\
\hline & MSEP3 & 0.683 & $<0.000$ & 1.073 \\
\hline \multirow[t]{2}{*}{ Marketing Implementation Capabilities } & MICA1 & 0.853 & $<0.001$ & 1.677 \\
\hline & MICA2 & 0.753 & $<0.001$ & 1.677 \\
\hline \multirow[t]{3}{*}{ Export Performance } & EXP1 & 0.864 & $<0.001$ & 1.247 \\
\hline & EXP3 & 0.806 & $<0.001$ & 1.251 \\
\hline & EXP4 & 0.709 & $<0.001$ & 1.138 \\
\hline
\end{tabular}

Apparently, Sample adequacy affects the validity of output. Prior research suggests that a sample size of 100 to 200 is usually a good starting point in carrying out path modeling (Hoyle, 1995). Therefore, the sample size of this study is 280 respondents and 54 arrows pointing to latent variable those are more than adequate to analysis

\subsubsection{Collinearity Diagnosis}

The Existence of multi co-linearity falsely inflates the standard errors and certain model parameters may sometimes become unstable (Kock, 2011). To assess the degree of multicollinearity, variance inflation factors (VIFs) are evaluated for each of the predictor variables. As shown in Table 7 all VIFs value were less than 3.3 ranging from 1.081 to 1.921 meeting the recommended threshold values (VIF of 5 or lower and a Tolerance level of 0.2 or higher) which points to the nonexistence of multicollinearity.

Table 7. Block Variance Inflation Factor (VIF)

\begin{tabular}{lllllllll}
\hline & \multicolumn{2}{l}{ Block variance inflation factors } & & & & \\
& \cline { 2 - 8 } & Inform & Finaid & Edtrain & Legal & marsel & Marstr & Miscell \\
\hline MaImpca & 1.535 & 1.392 & 1.319 & 1.33 & 1.491 & 1.083 & 1.498 \\
Experf & 1.882 & 1.307 & 1.786 & 1.843 & 1.299 & 1.279 & 1.921 & 1.308 \\
\hline
\end{tabular}

Note. These VIFs are for the latent variables on each column (predictors), with reference to the latent variables on each row (criteria). 
The VIFs are calculated based on a full collinearity test (Kock \& Lynn, 2012), which enables the identification of not only vertical but also lateral collinearity, and allows for a test of collinearity involving all latent variables in a model. A rule of thumb rooted in the use of this software for many SEM analyses in the past suggests that full collinearity VIFs of 3.3 or lower suggest the existence of no multicollinearity in the model and no common method bias (Hair et al., 2009). In this study, the Full collinearity VIFs of all latent variables were less than 3.3 as shown in Table 7.

\subsection{A Model Fit and Quality Indices}

The model includes 54 items describing 9 latent constructs: 'Information-Related to Government EPPs', 'financial aid-Related to Government EPPs', 'legal-Related to Government EPPs', 'market selection-Related to Government EPPs', 'market strategies-Related to Government EPPs' and 'miscellaneous -Related to Government EPPs' are independent constructs, 'market implementation capabilities' is a mediating construct, and 'export performance' is dependent constructs (see Figure 2). The structural equation modeling (SEM) WarpPLS 5.0 software was used to provide the necessary analysis to serve the objectives of this study. The measurement model test resulted in statistically accepted goodness of fit between the data and the proposed measurement model as shown in Table 8 .

Table 8. Model fit and quality indices

\begin{tabular}{lll}
\hline Model fit and quality indices & & \\
\hline Measure & Value & p-value \\
\hline Average path coefficient (APC) & 0.208 & $\mathrm{P}<0.001$ \\
Average R-squared (ARS) & 0.590 & $\mathrm{P}<0.001$ \\
Average adjusted R-squared (AARS) & 0.557 & $\mathrm{P}<0.001$ \\
Average block VIF (AVIF) & 1.538 & acceptable if $<=5$, ideally $<=3.3$ \\
Average full co-linearity VIF (AFVIF) & 2.092 & acceptable if $<=5$, ideally $<=3.3$ \\
Tenenhaus GoF (GoF) & 0.589 & small $>=0.1$, medium $>=0.25$, large $>=0.36$ \\
Simpson's paradox ratio (SPR) & 1.000 & acceptable if $>=0.7$, ideally $=1$ \\
R-squared contribution ratio (RSCR) & 1.000 & acceptable if $>=0.9$, ideally $=1$ \\
Statistical suppression ratio (SSR) & 1.000 & acceptable if $>=0.9$ \\
Nonlinear bi-variate causality direction ratio (NLBCDR) & 1.000 & acceptable if $>=0.9$ \\
\hline
\end{tabular}

When assessing the model fit with the data, several criteria were used. In this study, both the AVIF and AFVIF is 1.538 and 2.092, respectively achieving the recommended level equal to or lower than 3.3, particularly in models where most of the variables are measured through two or more indicators. Similarly, to the ARS, the GoF index, referred to as "Tenenhaus GoF", is a measure of a model's explanatory power. Tenenhaus et al. (2005) defined the GoF as the square root of the product between what they refer to as the average communality index and the ARS. The GOF of this study is 0.589 which range in to large explanatory power.

The SPR index of this study is 1.000 above 0.7 and confirms a model is free from Simpson's paradox instances (Pearl, 2009; Wagner, 1982) meaning that there are no instances of Simpson's paradox in a model. A Simpson's paradox instance is a possible indication of a causality problem, suggesting that a hypothesized path is either implausible or reversed. The weight-loading signs (WLS) of all indicators were positive in this study meaning that there is no a negative Weight loading making a negative contribution to the R-squared of its latent variable.

The RSCR index of this study is 1.000 which shows model is free from negative R-squared contributions, which occur together with Simpson's paradox instances (Pearl, 2009; Wagner, 1982). SSR, an instance of statistical suppression occurs when a path coefficient is greater, in absolute terms, than the corresponding correlation associated with a pair of linked variables. An SSR value of the study is 1.00 meaning that at least 100 percent of the paths in a model are free from statistical suppression.

Finally, the values of NLBCDR of the research is 1.000 meaning that in at least 100 percent of path-related instances in a model the support for the reversed hypothesized direction of causality is weak or less. Here "less" may mean that the support for reversed hypothesized direction of causality is less than weak (neutral), or that the hypothesized direction of causality is supported.

\subsubsection{Explanation of Target Endogenous Variable Variance}

Adjusted R-squared coefficients (Theil, 1958; Wooldridge, 1991) are equivalent to R-squared coefficients, with the key difference that they correct for spurious increases in R-squared coefficients due to predictors that add no explanatory value in each latent variable block. In marketing research, $\mathrm{R} 2$ of 0.75 is substantial, 0.50 is moderate, 
and 0.25 is weak. Therefore, the coefficient of determination, $\mathrm{R}^{2}$ is 0.52 for the marketing implementation capability endogenous latent variable.

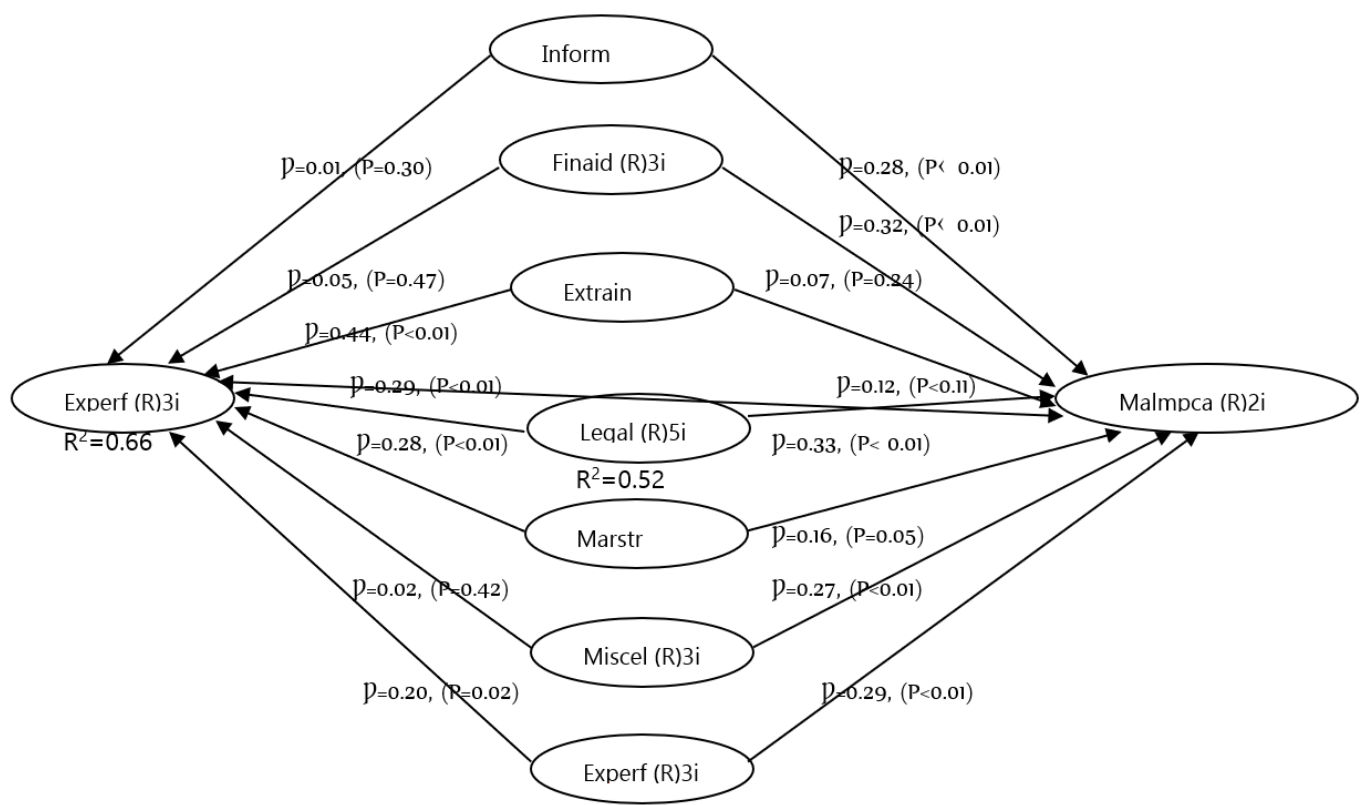

Figure 2. EPP mediated by marketing implementation capability model path Coefficient and $\mathrm{p}$ values

Note. Inform: - Information-Related to Government EPPs', Finaid: - 'financial aid-Related to Government EPPs', Legal: - 'legal-Related to Government EPPs', Marsel: - 'market selection-Related to Government EPPs', Marstr: - 'market strategies-Related to Government EPPs' and Miscell: - 'miscellaneous -Related to Government EPPs', Experf: 'export performance'.

This means that the seven latent variables (Inform, Finaid, Edtrain, Legal, Marsel, Marstr and Miscell) strongly explain $52 \%$ of the variance in marketing implementation capability. In addition, the coefficient of determination, $\mathrm{R} 2$, is 0.66 for the export performance endogenous latent variable. This means that the eight constructs latent variables moderately explain $66 \%$ of the variance in export performance in Ethiopia.

\subsubsection{Hypothesis Testing}

In nonlinear relationships, the path coefficient is given by the first derivative of the nonlinear function that describes the relationship. In the calculation of $\mathrm{P}$ values, a one-tailed test is generally recommended if the coefficient is assumed to have a sign (positive or negative), which should be reflected in the hypothesis that refers to the corresponding association (Kock, 2014). Hence this model reports one-tailed P values for path coefficients.

Table 9. Hypothesis testing

\begin{tabular}{|c|c|c|c|c|}
\hline Hypothesis & Effects & Path Coefficient & P-value & Remarks \\
\hline H1 & Inform $\rightarrow$ MaImpca & 0.284 & $<0.001 * * *$ & Supported \\
\hline $\mathrm{H} 2$ & Finaid $\rightarrow$ MaImpca & 0.316 & $<0.001 * * *$ & Supported \\
\hline H3 & EdTrain $\rightarrow$ MaImpca & 0.069 & 0.241 & Not Supported \\
\hline $\mathrm{H} 4$ & Legal $\rightarrow$ MaImpca & -0.332 & $<0.001 * * *$ & Not Supported \\
\hline H5 & Marsel $\rightarrow$ MaImpca & -0.160 & 0.049 & Not Supported \\
\hline H6 & Marstr $\rightarrow$ MaImpca & 0.269 & $0.002 * *$ & Supported \\
\hline H7 & Miscell $\rightarrow$ MaImpca & 0.287 & $<0.001 * * *$ & Supported \\
\hline $\mathrm{H} 8$ & Inform $\rightarrow$ MaImpca $\rightarrow$ Experf & -0.008 & 0.47 & Not Supported \\
\hline H9 & Finaid $\rightarrow$ MaImpca $\rightarrow$ Experf & 0.051 & 0.304 & Not Supported \\
\hline H10 & EdTrain $\rightarrow$ MaImpca $\rightarrow$ Experf & 0.439 & $<0.001 * * *$ & Supported \\
\hline H11 & Legal $\rightarrow$ MaImpca $\rightarrow$ Experf & 0.291 & $<0.001 * * *$ & Supported \\
\hline H12 & Marsel $\rightarrow$ MaImpca $\rightarrow$ Experf & 0.282 & $<0.001 * * *$ & Supported \\
\hline H13 & Marstr $\rightarrow$ MaImpca $\rightarrow$ Experf & -0.02 & 0.419 & Not Supported \\
\hline H14 & Miscell $\rightarrow$ MaImpca $\rightarrow$ Experf & 0.199 & $0.019 * *$ & Not Supported \\
\hline H15 & MaImpca $\rightarrow$ Experf & 0.117 & 0.114 & Not Supported \\
\hline
\end{tabular}

Note. $* * *$ Significance at $p<0.001, * *$ Significance at $p<0.05$. 
Therefore, this research report provides $\mathrm{P}$ values associated with path coefficients, which are more meaningful than T-values for hypothesis testing purposes. This is due to the fact that $\mathrm{P}$ values reflect not only the strength of the relationship (which is already provided by the path coefficient itself) but also the power of the test, which increases with sample size. The larger the sample size, the lower a path coefficient has to be to yield a statistically significant $\mathrm{P}$ value (Kock, 2015). The analysis of the path model that represents the relationships among the 9 constructs in this study. There was a good model fit and seven out of fifteen hypotheses were significant.

Table 10. Mediating role of market implementation capability

\begin{tabular}{lllll}
\hline Hypothesis & Direct Effect & Indirect Effect & Status & Evidence \\
\hline H8 & 0.284 & -0.008 & Not mediate & Unsupported \\
H9 & 0.316 & 0.051 & Not mediate & Unsupported \\
H10 & 0.069 & 0.1439 & Mediate & Supported \\
H11 & -0.332 & 0.291 & Mediate & Supported \\
H12 & -0.160 & 0.282 & Mediate & Supported \\
H13 & 0.269 & -0.020 & Not mediate & Unsupported \\
H14 & 0.287 & 0.199 & Not mediate & Unsupported \\
\hline
\end{tabular}

Table 10 shows that the direct and indirect effect of EPPs estimates and the mediating effect. Hence, market implementation capability mediates the effect of education and training development related government export promotion program, Legal related government export promotion program, market selection related government export promotion program on export performance. But market implementation capability doesn't mediate the effect of information related government export promotion program; financial aid related government export promotion program; marketing strategy related government export promotion program and miscellaneous government export promotion program on export performance since the indirect effect is less than the direct effect.

\section{Conclusion}

The Research Model demonstrated the effect of export promotion programs (EPPs) on export performance of Ethiopian exporting Companies with the mediating role of marketing implementation capabilities. The findings of the study provided supporting evidence for the partial mediating role of Market Implementation capability between Government Epps and export performance. This investigation provided an empirical evidence to substantiate the rational use of EPPs and marketing implementation capabilities contributing to the export literature in the developing countries. Information related EPPs, financial aid-related EPPs, Marketing Strategy-Related EPPs, Miscellaneous-Related EPPs have a positive influence on the Marketing Implementation Capabilities. However, marketing implementation capabilities did not mediate Information-related EPPs, financial aid-related EPPs, Marketing Strategy-Related EPPs, Miscellaneous-Related EPPs on export performance. The finding of the study with partial mediation role of marketing implementation capabilities on some elements of EPPs calls for further examination with respect to the dynamic exporting context of each country. Furthermore, International trade policy makers of each country should need to design Country specific EPPs to enhance their exporting performance. Most probably, awareness creation and appreciation of these EPPs might have not been communicated through appropriate media to the target Exporting Companies. In the light of the growing diversity, complexity, and volatility of the international business environment and the exporting country's context, governments EPPs support is required to be both attractive and flexible in enhancing the abilities of exporting companies. The study illustrated how government EPPs (financial, informational, education/training, legal, market targeting/market selection, marketing strategy and miscellaneous programs) will be of much help for exporting companies to overcome export related challenges and achieve superior Export Performance.

\subsection{Managerial Implications}

Assessment of export promotion programme effectiveness is critical for the success of exporting companies. The study findings indicated that the use of export promotion programmes has a positive and significant effect on export Performance. This indicates that Exporting Company managers, who used export promotion programme support are more successful in the target export market than those who do not. Results of the total model also revealed that market implementation capability mediates the effect of education and training development related government EPPs, Legal related government EPPs, and market selection-related government Epps on export 
performance positively and significantly. On the other hand, market implementation capability doesn't mediate the effect of information related government EPPs, financial aid-related government EPPs, Marketing strategy related government EPPs, and miscellaneous government EPPs, on export performance since the direct effect is less than the indirect effect. Managers can reduce their uncertainty and perceived risk of exporting by using export promotion programmes. Uncertainty and perceived risk can be reduced by giving export information and advice, marketing support, financial support and guarantees, and promotional activities abroad, developing managers' positive perception toward international operations. Therefore, Government sponsored Export Promotion Programs (EPPS) need to be designed to assist Ethiopian exporters in their Target export Markets. This study provides a guideline for managers of exporting Companies to benefit from export promotion programmes to build marketing capability and enhance commitment to be successful in international operations. Export promotion programmes represent readily available external sources of information and experiential knowledge, and provide the exporting Company with an external capacity to cope with the complexities of exporting (Gencurk \& Kotabe, 2001).

\subsection{Limitations of the Study and Future Research Direction}

There are many inherent constraints and limitations that may affect the generalizability of the results of this study. First, this study is based on export promotion programmes employed by Ethiopian Exporting firms and cannot be generalized for other countries. Secondly, the data analyzed was one shot and cross-sectional rather than longitudinal. Being a one-shot cross-sectional study, the result doesn't show the moving picture of export promotion program's impact on export performance. These limitations of the study provide the basis for future research. Researchers can carry out a research in one of the following areas: First, future research can be directed on the influence of EPPs to selected exporting companies/industries in Ethiopia. Second, the aggregate impact of EPP can be investigated, because it is the individual elements or programmes of EPPs that were analyzed in the present study. Third, if resources are made available, a comparative study on the role of EPPs on export performance can be carried out between Ethiopia and any other developing country in Africa. Fourth, a researcher can use objective measures or secondary data instead of subjective measures used in this study. Fifth, the role of EPPs on export performance in relation to each stage of the internationalization process of exporting Companies (reactive exporter, active exporter and committed exporter) can be studied in order to measure whether Exporting Companies at different stages of the internationalization process are influenced differently.

\section{References}

Barclay, D., Higgins, C., \& Thompson, R. (1995). The Partial Least Squares (PLS) Approach to Causal Modeling: Personal Computer Adoption and Use as an Illustration. Technology Studies, 2(2), 285-309.

Biel, R. (2000). The New Imperialism: Crisis and contradictions in North-South relations. London: Zed Books.

Borooah, V. K. (2003). Market Failure an Economic Analysis of its Causes and Consequences. Ulster: Ulster University Press. Retrieved June 25, 2021, from http://www.borooah.com/Teaching/Microeconomics/Market_\%20Failure.pdf

Boso, N., Cadogan, J. W., \& Story, V. M. (2012). Complementary effect of entrepreneurial and market orientations on export new product success under differing levels of competitive intensity and financial capital. International Business Review, 21(4), 667-681. https://doi.org/10.1016/j.ibusrev.2011.07.009

Cavusgil, S. T., \& Shaoming, Z. (1994). Marketing Strategy-Performance Relationship: An Investigation of the Empirical Link in Export Market Ventures. Journal of Marketing, 58(January), 1-21. https://doi.org/10.1177/002224299405800101

Cavusgil, S. T., \& Yeoh, P. L. (1994). Public Sector Promotion of U.S. Export Activity: A Review and Directions for the Future. Journal of Public Policy and Marketing, 13(1), 76-84. https://doi.org/10.1177/074391569401300106

Chin, W. W., Marcolin, B. L., \& Newsted, P. R. (2002). A partial least squares latent variable modeling approach for measuring interaction effects: Results from a Monte Carlo simulation study and an electronic-mail emotion/adoption study. Information Systems Research, 14(2), 189-218. https://doi.org/10.1287/isre.14.2.189.16018

Fahy, J., Hooley, G. J., Cox, A. J., Beracs, J., Fonfara, K., \& Snoj, B. (2000). The development and impact of marketing capabilities in central Europe. Journal of International Business Studies, 31(1), 63-81. https://doi.org/10.1057/palgrave.jibs.8490907

Fang, E., \& Zou, S. (2009). Antecedents and consequences of marketing dynamic capabilities in international 
joint ventures. Journal of International Business Studies, 40, 742-761. https://doi.org/10.1057/jibs.2008.96

Fornell, C., \& Larcker, D. F. (1981). Evaluating structural equation models with unobservable variables and measurement error. Journal of Marketing Research, 18(1), 39-50. https://doi.org/10.1177/002224378101800104

Freixanet, J. (2012). Export Promotion Programs: Their Impact on Companies' Internationalization Performance and Competitiveness. International Business Review, 21, 1065-1086. https://doi.org/10.1016/j.ibusrev.2011.12.003

Gallego, M. A., Hidalgo, E. R., Acedo, F. J., Casillas, J. C., \& Moreno, A. M. (2009). The relationship between timing of entry into a foreign market, entry mode decision and market selection. Society, 18(2-3), 306-331. https://doi.org/10.1177/0961463X09337843

Gençtürk, E., \& Kotabe, M. (2001). The Effect of Export Assistance Program Usage on Export Performance: A Contingency Explanation. Journal of International Marketing, 9(2), 51-72. https://doi.org/10.1509/jimk.9.2.51.19886

Gerashchenko, A. (1966). Economic Backwardness in Historical Perspective. Harvard university press.

Hair, J. F., Black, W. C., Babin, B. J., \& Anderson, R. E. (2009). Multivariate data analysis. Upper Saddle River, NJ: Prentice Hall.

Hair, J. F., Black, W. C., Babin, B. J., \& Anderson, R. E. (2010). Multivariate Data Analysis (7th ed.). Prentice Hall, Upper Saddle River, New Jersey.

Hair, J., Rolph, A., Ronald, T., \& William, B. (1998). Multivariate Data Analysis (5th ed.). New Jersey: Prentice-Hall International.

Heckscher, E. (1991). The Effect of Foreign Trade on the Distribution of Income. In Bertil Ohlin and Eli Heckscher. Heckscher.

Holmes-Smith, P. (2007). An applied introductory course in structural equation modelling using AMOS (p. 193). School Research Evaluation and Measurement Services (SREAMS), Melbourne. Ohlin Trade Theory Cambridge: The MIT Press.

Hoyle, R. H. (1995). The structural equation modeling approach: Basic concepts and fundamental issues. In R. H. Hoyle (Ed.), Structural equation modeling: Concepts, issues, and applications (pp. 1-15). Sage Publications, Inc.

Jaramillo, C. (1992). The Basic Function of National Trade Promotion Organizations. International Trade Forum, July/September.

Kock, N. (2011). A mathematical analysis of the evolution of human mate choice traits: Implications for evolutionary psychologists. Journal of Evolutionary Psychology, 9(3), 219-247. https://doi.org/10.1556/JEP.9.2011.3.1

Kock, N. (2014). One-tailed or two-tailed P values in PLS-SEM? Laredo, TX: ScriptWarp Systems. https://doi.org/10.4018/ijec.2015040101

Kock, N. (2017). WarpPLS User Manual: Version 6.0. Laredo, TX: ScriptWarp Systems.

Kock, N., \& Gaskins, L. (2014). The mediating role of voice and accountability in the relationship between Internet diffusion and government corruption in Latin America and Sub-Saharan Africa. Information Technology for Development, 20(1), 23-43. https://doi.org/10.1080/02681102.2013.832129

Kock, N., \& Lynn, G. S. (2012). Lateral collinearity and misleading results in variance-based SEM: An illustration and recommendations. Journal of the Association for Information Systems, 13(7), 546-580. https://doi.org/10.17705/1jais.00302

Kumku, H. T., Harcar, T., \& Kumcu, M. E. (1995). Managerial Perceptions of the Adequacy of Export Incentive Programs: Implications for Export-led Economic Development Policy. Journal of Business Research, 32(2), 163-174. https://doi.org/10.1016/0148-2963(94)00038-G

Lages, F. L., \& Montgomery, B. D. (2005). The Relationship between Export Assistance and Performance Improvement in Portuguese Export Ventures: An Empirical Test of the Mediating Role of Pricing Strategy

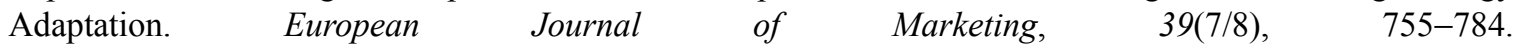
https://doi.org/10.1108/03090560510601752

Lages, L. F., \& Cristiana, R. L. (2004). The STEP Scale: A Measure of Short-Term Export Performance 
Improvement. Journal of International Marketing, 12(1), 36-56. https://doi.org/10.1509/jimk.12.1.36.25647

Lederman, D., Olarreaga, M., \& Payton, L. (2010). Export promotion agencies: Do they work? Journal of Development Economics, 91, 257-265. https://doi.org/10.1016/j.jdeveco.2009.09.003

Leonidou, L. C. (1995a). Empirical Research on Export Barriers: Review, Assessment, and Synthesis. Journal of International Marketing, 3(1), 29-43. https://doi.org/10.1177/1069031X9500300103

Leonidou, L. C. (1995b). Export Barriers: Non-Exporters' Perceptions. International Marketing Review, 12(1), 4-25. https://doi.org/10.1108/02651339510080070

Leonidou, L. C. (2004). An analysis of the barriers hindering small business export development. Journal of Small Business Management, 42(3), 279-302. https://doi.org/10.1111/j.1540-627X.2004.00112.x

Leonidou, L. C., \& Katsikeas, C. S. (1996). The Export Development Process: An Integrative Review of Empirical Models. Journal of International Business Studies, 27, 517-551. https://doi.org/10.1057/palgrave.jibs.8490846

Leonidou, L. C., Palihawadana, D., \& Theodosiou, M. (2011). National export-promotion programs as drivers of organizational resources and capabilities: Effects on strategy, competitive advantage, and performance. Journal of International Marketing, 19(2), 1-29. https://doi.org/10.1509/jimk.19.2.1

Lewis, B. R. et al. (2005). A methodology for construct development in MIS research. European Journal of Information System, 14(4), 388-400. https://doi.org/10.1057/palgrave.ejis.3000552

Marandu, E. E. (1995). Impact of Export Promotion on Export Performance: A Tanzanian Study. Journal of Global Marketing, 9(1/2), 9-39. https://doi.org/10.1300/J042v09n01_02

Marcoulides, G. A., \& Saunders, C. (2006). PLS: A Silver Bullet? MIS Quarterly, 30, 2. https://doi.org/10.2307/25148727

Miller, R. B., \& Wichern, D. W. (1977). Intermediate business statistics: Analysis of variance, regression and time series. New York, NY: Holt, Rihehart and Winston.

Morgan, N., Katsikeas, C., \& Vorhies, D. (2012). Export marketing strategy implementation, export marketing capabilities and export venture performance. Journal of the Academy Marketing Science, 40, 271-289. https://doi.org/10.1007/s11747-011-0275-0

Morgan, N. A., Zou, S., Vorhies, D. W., \& Katsikeas, C. S. (2003). Experiential and informational knowledge, architectural marketing capabilities, and the adaptive performance of export ventures. Decision Sciences, 34(2), 287-321. https://doi.org/10.1111/1540-5915.02375

Mueller, R. O. (1996). Basic principles of structural equation modeling. New York, NY: Springer. https://doi.org/10.1007/978-1-4612-3974-1

Ohlin, B. (1991). The Theory of Trade. In Bertil Ohlin and Eli Heckscher, Heckscher-Ohlin Trade Theory. Cambridge: The MIT Press.

Pavlou, P. A., \& Fygenson, M. (2006). Understanding and prediction electronic commerce adoption: An extension of the theory of planned behavior. MIS Quarterly, 30(1), 115-143. https://doi.org/10.2307/25148720

Pearl, J. (2009). Causality: Models, reasoning, and inference. Cambridge, England: Cambridge University Press. https://doi.org/10.1017/CBO9780511803161

Samiee, S., \& Walters, P. G. P. (1991). Segmenting Corporate Exporting Activities: Sporadic Versus Regular Exporters. Journal of the Academy of Marketing Science, 19(2), 93-104. https://doi.org/10.1007/BF02726001

Seringhaus, F. H. R. (1986). The Impact of Government Export Marketing Assistance. International Marketing Review, summer, 55-66. https://doi.org/10.1108/eb008306

Shamsuddoha, A. K., Yunus, A. M., \& Ndubisi, N. O. (2009a). Impact of Government Export Assistance on Internationalization of SMEs from Developing Nations. Journal of Enterprise Information Management, 22(4), 408-422. https://doi.org/10.1108/17410390910975022

Shoham, A. (1998). Export Performance: A Conceptualization and Empirical Assessment. Journal of International Marketing, 6(3), 59-81. https://doi.org/10.1177/1069031X9800600308 
Tenenhaus, M., \& Esposito, V. V. (2005). PLS regression, PLS path modeling and generalized procrustean analysis: A combined approach for PLS regression, PLS path modeling and generalized multiblock analysis. Journal of Chemometrics, 19, 145-153. https://doi.org/10.1002/cem.917

Tesfom, G., \& Lutz, C. (2008). Evaluating the Effectiveness of Export Support Services in Developing Countries. A Customer (User) Perspective. International Journal of Emerging Markets, 3(4), 364-377. https://doi.org/10.1108/17468800810906075

Theil, H. (1958). Economic forecasts and policy. Amsterdam, Netherlands: North-Holland.

Theodosiou, M., \& Leonidou, L. C. (2003). Standardization versus Adaptation of International Marketing Strategy: An Integrative Assessment of the Empirical Research. International Business Review, 12(2), 141-171. https://doi.org/10.1016/S0969-5931(02)00094-X

Toften, K., \& Olsen, S. O. (2003). Export market information use, organizational knowledge, and firm performance: A conceptual framework. International Marketing Review, 20(1), 95-110. https://doi.org/10.1108/02651330310462284

Tsai, M. T., \& Shih, C.-M. (2004). The impact of marketing knowledge among managers on marketing capabilities and business performance. International Journal of Management, 21(4), 524-530.

Vorhies, D. W., \& Morgan, N. A. (2003). A configuration theory assessment of marketing organization fit with business strategy and its relationship with marketing performance. Journal of Marketing, 67, 100-115. https://doi.org/10.1509/jmkg.67.1.100.18588

Wagner, C. H. (1982). Simpson's paradox in real life. The American Statistician, 36(1), 46-48. https://doi.org/10.1080/00031305.1982.10482778

Weerawardena, \& Mavondo. (2011). Capabilities, innovation and competitive advantage. Industrial Marketing Management, 40(8), 1220-1223. -

Welch, L. S., \& Wiedersheim-Paul, F. (1980). Initial Exports-A Marketing Failure? Journal of Management Studies, October, 333-344. https://doi.org/10.1111/j.1467-6486.1980.tb00407.x

White, G., \& Wade, R. (1988). Developmental States and Markets in East Asia: An Introduction. In G. White (Ed.), Developmental States in East Asia. London: The Macmillan Press. https://doi.org/10.1007/978-1-349-19195-6

Wiklund, J., \& Shepherd, D. (2005). Entrepreneurial orientation and small business performance: A configurational approach. Journal of Business Venturing, 20(1), 71-91. https://doi.org/10.1016/j.jbusvent.2004.01.001

Wilkinson, T. J., \& Brouthers, L. E. (2000). An Evaluation of State Sponsored Promotion Programs. Journal of Business Research, 47, 229-236. https://doi.org/10.1016/S0148-2963(99)00097-1

Winters, L. (1991). International Economics. USA: Routledge. https://doi.org/10.4324/9780203308318

Wooldridge, J. M. (1991). A note on computing r-squared and adjusted r-squared for trending and seasonal data. Economics Letters, 36(1), 49-54. https://doi.org/10.1016/0165-1765(91)90054-O

Zou, S. M., \& Simona, S. (1998). The Determinants of Export Performance: A Review of the Empirical Literature Between 1987 and 1997. International Marketing Review, 15(5), 333-356. https://doi.org/10.1108/02651339810236290

\section{Copyrights}

Copyright for this article is retained by the author, with first publication rights granted to the journal.

This is an open-access article distributed under the terms and conditions of the Creative Commons Attribution license (http://creativecommons.org/licenses/by/4.0/). 